\title{
EVALUASI TINGKAT PELAYANAN RAMP SIMPANG SUSUN BAROS
}

\author{
Budi Hartanto Susilo, Ivan Imanuel \\ Program Studi Teknik Sipil, Fakultas Teknik, Universitas Kristen Maranatha \\ Jalan Prof. drg. Suria Sumantri, MPH. No. 65 Bandung 40164 \\ Email: budiharsus@yahoo.com
}

\begin{abstract}
ABSTRAK
Seiring pertumbuhan lalu lintas yang terus meningkat, perlu diselidiki mengenai kebutuhan peningkatan pelayanan Simpang Susun Baros dalam rangka meningkatkan pelayanan transportasi di wilayah Cimahi. Dalam penelitian ini, dilakukan penentuan tingkat pelayanan ramp berdasarkan derajat kejenuhan dan memperkirakan waktu peningkatan pelayanan berdasarkan pertumbuhan lalu lintas. Penelitian dilakukan hanya pada ramp '6001' dan ramp '6003' yang merupakan akses keluar Jalan Tol Pasteur. Ramp '6001' memiliki tingkat pelayanan "D" pada tahun 2014 dengan derajat kejenuhan sebesar 0,81. Volume lalu lintas ramp '6001' diperkirakan mencapai kapasitas jalan pada tahun 2027. Ramp '6003' memiliki tingkat pelayanan "B" pada tahun 2014 dengan derajat kejenuhan sebesar 0,46. Volume lalu lintas ramp '6003' diperkirakan mencapai kapasitas jalan pada tahun 2063 .
\end{abstract}

Kata kunci: Tingkat Pelayanan, Simpang Susun Baros, Derajat Kejenuhan, Pertumbuhan Lalu Lintas.

\begin{abstract}
Along with continuously increasing traffic growth, it is necessary to investigate about the necessity of service improvement on Baros Interchange in order to improve the transport services in Cimahi. This research aims to determine the ramp's level of service based on the density and estimate the time for service improvement based on traffic growth. The research is done on ramp '6001' and ramp '6003'only which are the exit ways of Pasteur Toll Road. The result of calculations shows that ramp '6001' has a " $D$ ” level of service in 2014 with density about 0,81. Traffic volume on ramp '6001' is estimated to reach its capacity in 2027. The ramp '6003' has a " $B$ " level of service in 2014 with density about 0,46. Traffic volume on ramp '6003' is estimated to reach its capacity in 2063.
\end{abstract}

Keywords: Level of Service, Baros Interchange, Degree of Saturation, Traffic Growth.

\section{PENDAHULUAN}

Meningkatnya aktivitas transportasi dapat menimbulkan kemacetan. Banyaknya kendaraan perlu diimbangi dengan kapasitas jalan yang memadai agar tidak menimbulkan kemacetan maupun kecelakaan. Salah satu solusi untuk menampung lalu lintas bervolume tinggi dengan aman dan efisien adalah dengan melakukan rekayasa terhadap sarana, prasarana, maupun lalu lintas transportasi. (AASHTO, 2011).

Seiring pertumbuhan lalu lintas yang terus meningkat, perlu diselidiki mengenai kebutuhan peningkatan pelayanan simpang susun Baros dalam rangka meningkatkan pelayanan transportasi di wilayah Cimahi sesuai dengan Peraturan Menteri Perhubungan Nomor KM 14 Tahun 2006 tentang Manajemen dan Rekayasa Lalu Lintas di Jalan Pasal 
6 ayat (1). Lokasi tempat dilakukan penelitian ditunjukkan pada Gambar 1. Penelitian dilakukan pada ramp '6001' dan ramp '6003' yang merupakan akses keluar jalan tol.

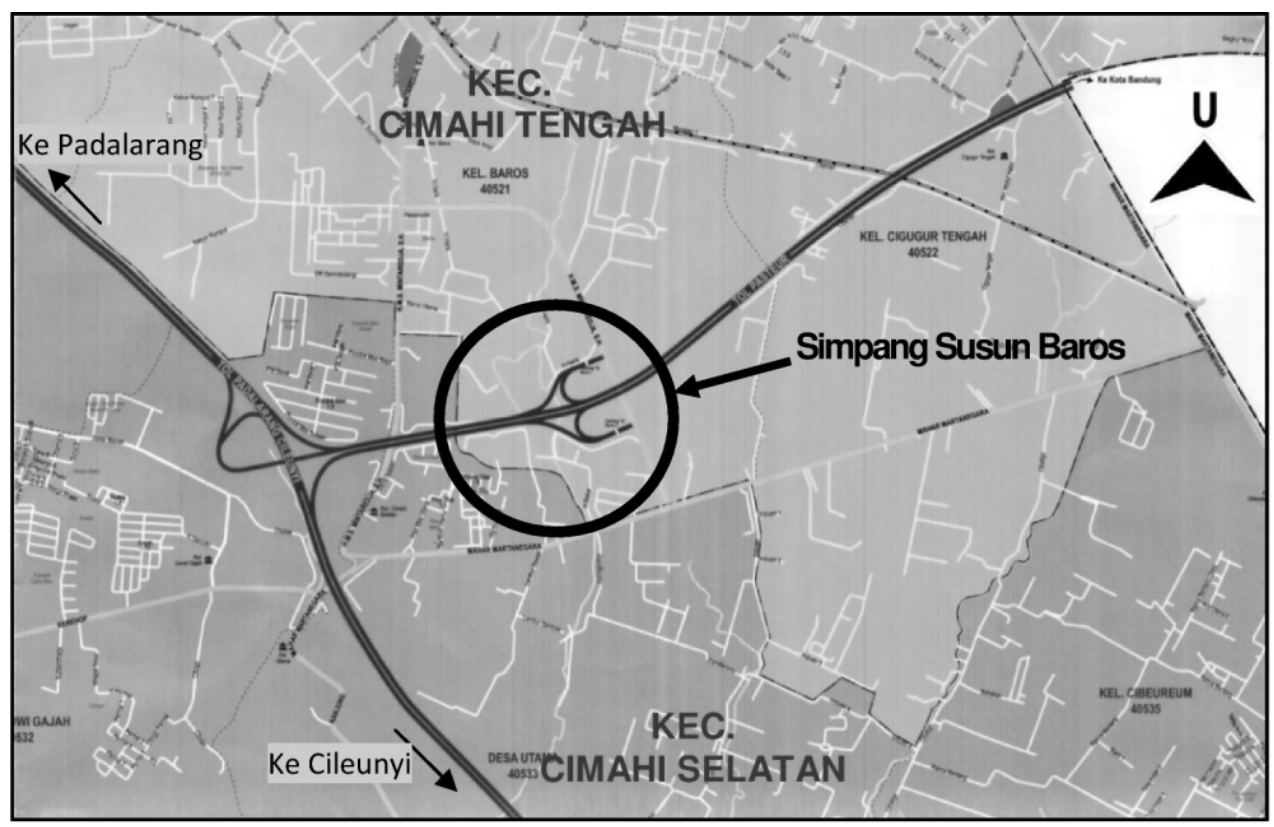

Gambar 1 Lokasi Penelitian

\section{TUJUAN PENELITIAN}

Tujuan penelitian adalah sebagai berikut:

1. Menentukan tingkat pelayanan ramp pada simpang susun Baros.

2. Memperkirakan waktu peningkatan pelayanan/umur rencana berdasarkan pertumbuhan lalu lintas.

\section{TINJAUAN PUSTAKA}

\subsection{Kapasitas Jalur Penghubung / Ramp}

Kapasitas didefinisikan sebagai arus maksimum yang melewati suatu titik pada suatu jalan yang dapat dipertahankan persatuan jam dalam kondisi yang berlaku. Kapasitas suatu ramp (C) dapat diperkirakan dengan menghitung kapasitas dengan metode perhitungan untuk jalan luar kota sebagai fungsi penampang melintang dan alinemen ramp tersebut. (Ditjen Bina Marga, 1997)

Perhitungan kapasitas untuk jalur penghubung/jalan luar kota ditunjukkan dengan Persamaan 1 (satuan smp/j).

$$
\mathrm{C}=\mathrm{C}_{0} \times \mathrm{FC}_{\mathrm{W}} \times \mathrm{FC}_{\mathrm{SP}} \times \mathrm{FC}_{\mathrm{SF}}
$$

dengan: 


$$
\begin{array}{ll}
\mathrm{C}_{0} & \text { = kapasitas dasar } \\
\mathrm{FC}_{\mathrm{W}} & =\text { faktor penyesuaian lebar jalan bebas hambatan } \\
\mathrm{FC}_{\mathrm{SP}} & =\text { faktor penyesuaian pemisahan arah (hanya untuk jalan tak terbagi) } \\
\mathrm{FC}_{\mathrm{SF}} & =\text { faktor penyesuaian hambatan samping }
\end{array}
$$

Kapasitas dasar $\left(\mathrm{C}_{0}\right)$ ditentukan berdasarkan tipe jalan dan tipe alinemen. Kapasitas dasar untuk jalan luar kota ditunjukkan pada Tabel 1.

Tabel 1 Kapasitas Dasar pada Jalan Luar Kota

\begin{tabular}{ll}
\hline $\begin{array}{l}\text { Tipe jalan / } \\
\text { Tipe alinemen }\end{array}$ & $\begin{array}{l}\text { Kapasitas dasar } \\
\text { (smp/jam/lajur) }\end{array}$ \\
\hline $\begin{array}{l}\text { Empat-lajur terbagi } \\
\text { - Datar }\end{array}$ & 1900 \\
- Bukit & 1850 \\
- Gunung & 1800 \\
Empat-lajur tak-terbagi & \\
- Datar & 1700 \\
- Bukit & 1650 \\
- Gunung & 1600 \\
Dua-lajur tak-terbagi & \\
- Datar & $3100^{*}$ \\
- Bukit & $3000^{*}$ \\
- Gunung & $2900^{*}$ \\
*: kapasitas dasar untuk 2 lajur \\
Sumber: Ditjen Bina Marga (1997)
\end{tabular}

Tipe alinemen ditentukan menggunakan informasi untuk lengkung horisontal dan naik serta turun vertikal. Tiga tipe alinemen umum disarankan untuk digunakan dalam analisis operasional dan perancangan ditunjukkan dalam Tabel 2.

Tabel 2 Tipe Alinemen

\begin{tabular}{ccc}
\hline Tipe alinemen & $\begin{array}{c}\text { Kemiringan vertikal } \\
(\mathrm{m} / \mathrm{km})\end{array}$ & $\begin{array}{c}\text { Lengkung horisontal } \\
(\mathrm{rad} / \mathrm{km})\end{array}$ \\
\hline Datar & $<10$ & $<1,0$ \\
Bukit & $10-30$ & $1,00-2,5$ \\
Gunung & $>30$ & $>2,5$ \\
\hline Sumber: Ditjen Bina Marga (1997)
\end{tabular}

Faktor penyesuaian kapasitas akibat lebar jalur lalu lintas $\left(\mathrm{FC}_{\mathrm{W}}\right)$ ditentukan berdasarkan tipe jalan dan lebar efektif jalur lalu lintas $\left(\mathrm{W}_{\mathrm{C}}\right)$ seperti ditunjukkan pada Tabel 3. Faktor penyesuaian akibat pemisahan arah $\left(\mathrm{FC}_{\mathrm{SP}}\right)$ hanya berlaku untuk jalan takterbagi sebagaimana ditunjukkan pada Tabel 4. Faktor penyesuaian akibat pemisah arah 
tidak dapat diterapkan pada jalan terbagi sehingga diasumsikan bernilai 1,0. Faktor penyesuaian kapasitas $\left(\mathrm{FC}_{\mathrm{SF}}\right)$ akibat hambatan samping berdasar pada lebar bahu $\left(\mathrm{W}_{\mathrm{S}}\right)$ dan hambatan samping seperti ditunjukkan pada Tabel 5.

Tabel 3 Faktor Penyesuaian Kapasitas Akibat Lebar Jalur Lalu Lintas

\begin{tabular}{|c|c|c|}
\hline Tipe jalan & $\begin{array}{l}\text { Lebar efektif jalur lalu lintas } \\
\qquad\left(\mathrm{W}_{\mathrm{C}}\right)(\mathrm{m})\end{array}$ & $\mathrm{FC}_{\mathrm{W}}$ \\
\hline \multirow{5}{*}{$\begin{array}{l}\text { Empat-lajur terbagi } \\
\text { Enam-lajur terbagi }\end{array}$} & Per lajur & \\
\hline & 3 & 0,91 \\
\hline & 3,25 & 0,96 \\
\hline & 3,5 & 1,00 \\
\hline & 3,75 & 1,03 \\
\hline \multirow{4}{*}{ Empat-lajur tak-terbagi } & 3 & 0,91 \\
\hline & 3,25 & 0,96 \\
\hline & 3,5 & 1,00 \\
\hline & 3,75 & 1,03 \\
\hline \multirow{8}{*}{ Dua-lajur tak-terbagi } & Total kedua arah & \\
\hline & 5 & 0,69 \\
\hline & 6 & 0,91 \\
\hline & 7 & 1,00 \\
\hline & 8 & 1,08 \\
\hline & 9 & 1,15 \\
\hline & 10 & 1,21 \\
\hline & 11 & 1,27 \\
\hline
\end{tabular}

Sumber: Ditjen Bina Marga (1997)

Tabel 4 Faktor Penyesuaian Kapasitas Akibat Pemisahan Arah

\begin{tabular}{ccccccc}
\hline \multicolumn{2}{c}{ Pemisahan arah SP \%-\% } & $50-50$ & $55-45$ & $60-40$ & $65-35$ & $70-30$ \\
\hline \multirow{2}{*}{$\mathrm{FC}_{\mathrm{SP}}$} & Dua-lajur 2/2 & 1,00 & 0,97 & 0,94 & 0,91 & 0,88 \\
\cline { 2 - 7 } & Empat-lajur 4/2 & 1,00 & 0,975 & 0,95 & 0,925 & 0,90
\end{tabular}

Sumber: Ditjen Bina Marga (1997) 
Tabel 5 Faktor Penyesuaian Kapasitas Akibat Hambatan Samping

\begin{tabular}{|c|c|c|c|c|c|}
\hline \multirow{2}{*}{$\begin{array}{l}\text { Tipe } \\
\text { Jalan }\end{array}$} & \multirow{2}{*}{$\begin{array}{l}\text { Kelas hambatan } \\
\text { samping (SFC) }\end{array}$} & \multicolumn{4}{|c|}{ Faktor penyesuaian akibat hambatan samping $\left(\mathrm{FC}_{\mathrm{SF}}\right)$} \\
\hline & & $\mathrm{W}_{\mathrm{S}} \leq 0,5 \mathrm{~m}$ & $\mathrm{~W}_{\mathrm{S}}=1 \mathrm{~m}$ & $\mathrm{~W}_{\mathrm{S}}=1,5 \mathrm{~m}$ & $\mathrm{~W}_{\mathrm{S}} \geq 2,0 \mathrm{~m}$ \\
\hline \multirow{5}{*}{$4 / 2 \mathrm{D}$} & VL & 0,99 & 1,00 & 1,01 & 1,03 \\
\hline & $\mathrm{L}$ & 0,96 & 0,97 & 0,99 & 1,01 \\
\hline & M & 0,93 & 0,95 & 0,96 & 0,99 \\
\hline & $\mathrm{H}$ & 0,90 & 0,92 & 0,95 & 0,97 \\
\hline & VH & 0,88 & 0,90 & 0,93 & 0,96 \\
\hline \multirow{5}{*}{$\begin{array}{l}2 / 2 \text { UD } \\
4 / 2 \text { UD }\end{array}$} & VL & 0,97 & 0,90 & 1,00 & 1,02 \\
\hline & $\mathrm{L}$ & 0,93 & 0,95 & 0,97 & 1,00 \\
\hline & $\mathrm{M}$ & 0,88 & 0,91 & 0,94 & 0,98 \\
\hline & $\mathrm{H}$ & 0,84 & 0,87 & 0,91 & 0,95 \\
\hline & VH & 0,80 & 0,83 & 0,88 & 0,93 \\
\hline
\end{tabular}

Sumber: Ditjen Bina Marga (1997)

\subsection{Komposisi Lalu Lintas}

Satuan mobil penumpang (smp) adalah satuan untuk mengonversikan jenis-jenis kendaraan yang berbeda kepada satu jenis kendaraan standar yaitu mobil penumpang standar. Ekivalensi mobil penumpang (EMP) adalah angka atau nilai ekivalensi dari macam-macam kedaraan terhadap mobil penumpang standar berdasarkan kecepatan, percepatan, kekuatan mesin, dan dimensi kendaraan (Susilo, 2015). Nilai ekivalensi jalan bebas hambatan yang digunakan diasumsikan sebagai ekivalensi mobil penumpang pada jalaan terbagi dua arah empat lajur (MW 4/2D) seperti ditunjukkan pada Tabel 6 dengan pengelompokan kendaraan dengan pengelompokan kendaraan menjadi kendaraan ringan (LV), kendaraan berat menengah (MHV), truk besar (LT), bus besar (LB). Dalam pembagian ini kendaraan golongan I (sedan, jip, pick up/truk kecil) termasuk kategori LV, golongan II (truk 2 as) termasuk kategori MHV, sementara golongan III, IV, dan V (truk 3 as atau lebih) termasuk kategori LT (Kepmenpu No.370/KPTS/M/2007). 
Tabel 6 Koefisien Ekivalensi Mobil Penumpang (MW 4/2D)

\begin{tabular}{|c|c|c|c|c|c|}
\hline \multirow{2}{*}{$\begin{array}{c}\text { Tipe } \\
\text { Alinemen }\end{array}$} & \multicolumn{2}{|c|}{$\begin{array}{c}\text { Arus lalu lintas per arah } \\
\text { (kend/jam) }\end{array}$} & \multicolumn{3}{|c|}{ EMP } \\
\hline & 2 lajur & 1 lajur & MHV & $\mathrm{LB}$ & LT \\
\hline \multirow{4}{*}{ Datar } & 0 & 0 & 1,2 & 1,2 & 1,6 \\
\hline & 1250 & 625 & 1,4 & 1,4 & 2,0 \\
\hline & 2250 & 1125 & 1,6 & 1,7 & 2,5 \\
\hline & $\geq 2800$ & $\geq 1400$ & 1,3 & 1,5 & 2,0 \\
\hline \multirow{4}{*}{ Bukit } & 0 & 0 & 1,8 & 1,6 & 4,8 \\
\hline & 900 & 450 & 2,0 & 2,0 & 4,6 \\
\hline & 1700 & 850 & 2,2 & 2,3 & 4,3 \\
\hline & $\geq 2250$ & $\geq 1125$ & 1,8 & 1,9 & 3,5 \\
\hline \multirow{4}{*}{ Gunung } & 0 & 0 & 3,2 & 2,2 & 5,5 \\
\hline & 700 & 350 & 2,9 & 2,6 & 5,1 \\
\hline & 1450 & 725 & 2,6 & 2,9 & 4,8 \\
\hline & $\geq 2000$ & $\geq 1000$ & 2,0 & 2,4 & 3,8 \\
\hline
\end{tabular}

Sumber: Ditjen Bina Marga (1997)

\section{3 . Lalu Lintas Harian Rata-Rata Tahunan (LHRT)}

Lalu Lintas Harian Rata-Rata Tahunan (LHRT) adalah jumlah lalu lintas kendaraan rata-rata yang melewati satu jalur jalan selama 24 jam dan diperoleh dari data selama satu tahun penuh. (Sukirman, 1999) LHRT dihitung dengan Persamaan 2.

$$
\text { LHRT }=\frac{\text { Jumlah kendaraan selama } 1 \text { tahun }}{365}
$$

\section{4 . Volume Jam Rencana (VJR)}

Volume Jam Rencana (VJR) adalah perkiraan volume lalu lintas perjam pada jam sibuk tahun rencana. Volume jam rencana ditentukan dari lalu lintas harian dengan asumsi bahwa volume tersebut tidak terlalu besar atau terlalu kecil dan berada pada tumit lengkung grafik arus lalu lintas tahunan. (Sukirman, 1999) VJR dapat dihitung dengan Persamaan 3.

$$
\mathrm{VJR}=\mathrm{LHRT} \times \mathrm{K} \times \frac{\mathrm{SP}}{100}
$$

dengan:

$\mathrm{K}$ = faktor pemilihan jam sibuk (untuk jalan bebas hambatan, bernilai 11\%)

$\mathrm{SP}=$ faktor pembagian arus lalu lintas (untuk jalan satu arah, bernilai 100) 


\section{5 . Derajat Kejenuhan}

Derajat kejenuhan (DS) didefinisikan sebagai rasio arus terhadap kapasitas, digunakan sebagai faktor kunci dalam penentuan tingkat kinerja suatu simpang. Derajat kejenuhan seringkali disebut sebagai rasio volume kapasitas atau v/c rasio. Derajat kejenuhan dapat dihitung dengan Persamaan 4.

$$
\mathrm{DS}=\frac{\mathrm{VJR}}{\mathrm{C}}
$$

\section{6 . Tingkat Pelayanan}

Tingkat pelayanan adalah tolok ukur yang digunakan untuk menyatakan kualitas pelayanan suatu jalan. Tamin (2000) memberikan hubungan antara tingkat pelayanan dengan persentase kecepatan dari kecepatan bebas dan tingkat kejenuhan sebagaimana ditunjukkan pada Tabel 7.

Tabel 7 Indeks Tingkat Pelayanan berdasarkan Kecepatan Arus Bebas dan Tingkat

$$
\text { Kejenuhan Lalu Lintas }
$$

\begin{tabular}{ccc}
\hline Tingkat pelayanan & \% dari kecepatan bebas & Tingkat kejenuhan lalu lintas \\
\hline A & $\geq 90$ & $\leq 0,35$ \\
\hline B & $\geq 70$ & $\leq 0,54$ \\
\hline C & $\geq 50$ & $\leq 0,77$ \\
\hline D & $\geq 40$ & $\leq 0,93$ \\
\hline E & $\geq 33$ & $\leq 1,0$ \\
\hline F & $<33$ & $>1$ \\
\hline
\end{tabular}

Sumber: Tamin (2000)

\section{7 . Pertumbuhan Lalu Lintas}

Volume lalu lintas akan bertambah sesuai dengan umur rencana atau sampai pada tahap kapasitas jalan dicapai dengan faktor pertumbuhan lalu lintas yang dapat ditentukan. Hal ini digambarkan pada Persamaan 5. Faktor/tingkat pertumbuhan lalu lintas (i) dapat didefinisikan sebagai besarnya peningkatan volume lalu lintas dalam satu tahun (Susilo, 1999). 


$$
\mathrm{V}_{\mathrm{T}}=\mathrm{V}_{0} \times(\mathrm{i}+1)^{\mathrm{n}^{\prime}}
$$

dengan:

$\mathrm{V}_{\mathrm{T}}$ : Volume pada akhir umur rencana

$\mathrm{V}_{0}$ : Volume pada awal umur rencana

$\mathrm{n}^{\prime}$ : Umur rencana

Dengan mengasumsikan $n^{\prime}=1$ tahun, tingkat pertumbuhan lalu lintas dapat ditentukan dengan Persamaan 6.

$\mathrm{i}=\frac{\mathrm{V}_{\mathrm{T}}-\mathrm{V}_{0}}{\mathrm{~V}_{0}}$

\section{METODE PENELITIAN DAN PENGUMPULAN DATA}

\subsection{Metode Penelitian}

Metode penelitian yang digunakan adalah seperti ditunjukkan pada Gambar 2.

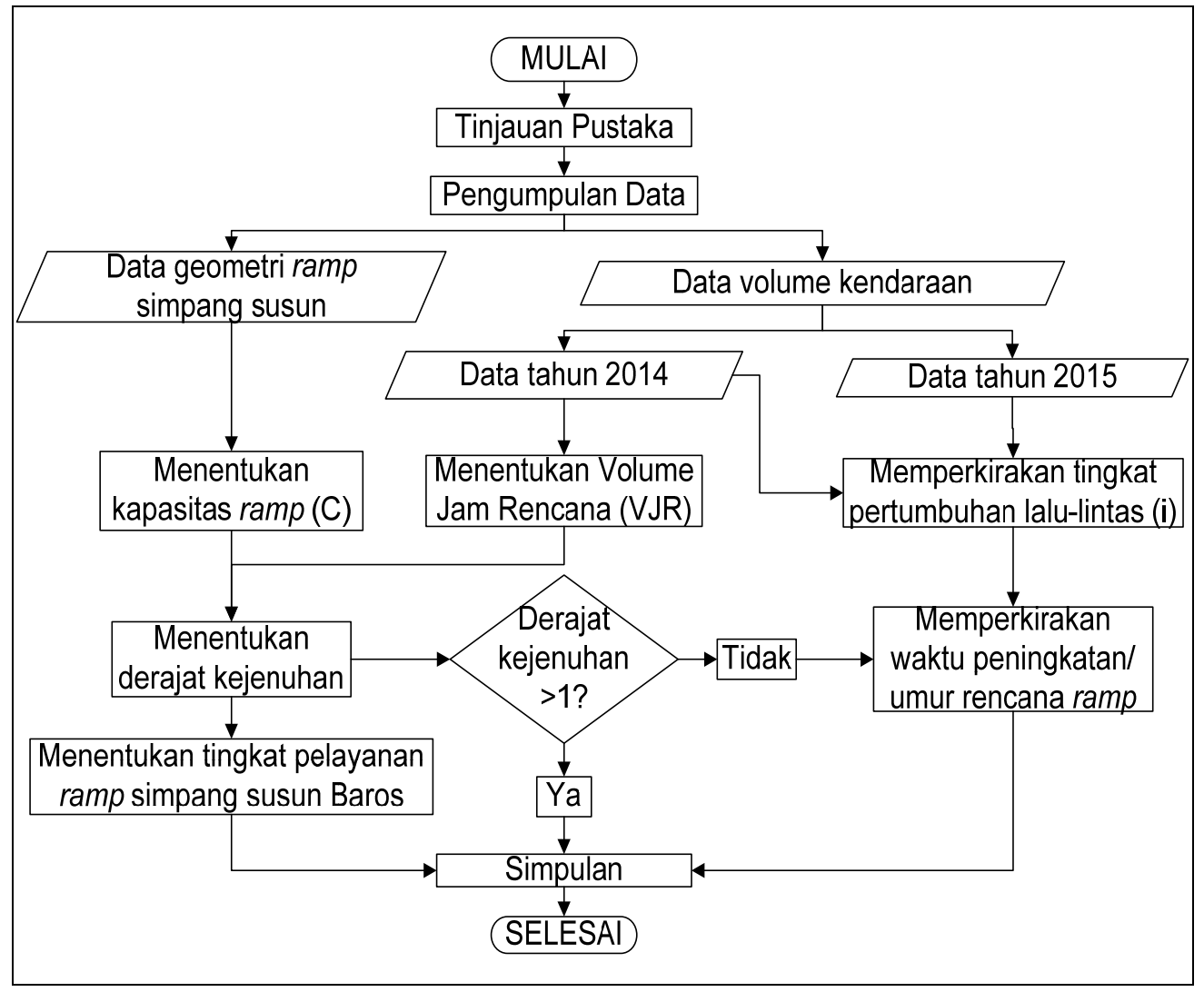

Gambar 2 Diagram Alir Penelitian 


\subsection{Pengumpulan Data}

Data geometri ramp simpang susun Baros diperoleh dari As Built Drawing Simpang Susun Baros. Data geometri lengkung ramp '6001' dan ramp '6003' yang diperlukan dalam penelitian ini berupa jumlah lajur, kelandaian maksimum $\left(\mathrm{g}_{\text {maks }}\right)$, lebar jalan (b), dan lebar bahu jalan terkecil $\left(\mathrm{W}_{\mathrm{S}}\right)$. Adapun denah simpang susun Baros ditunjukkan pada Gambar 3.

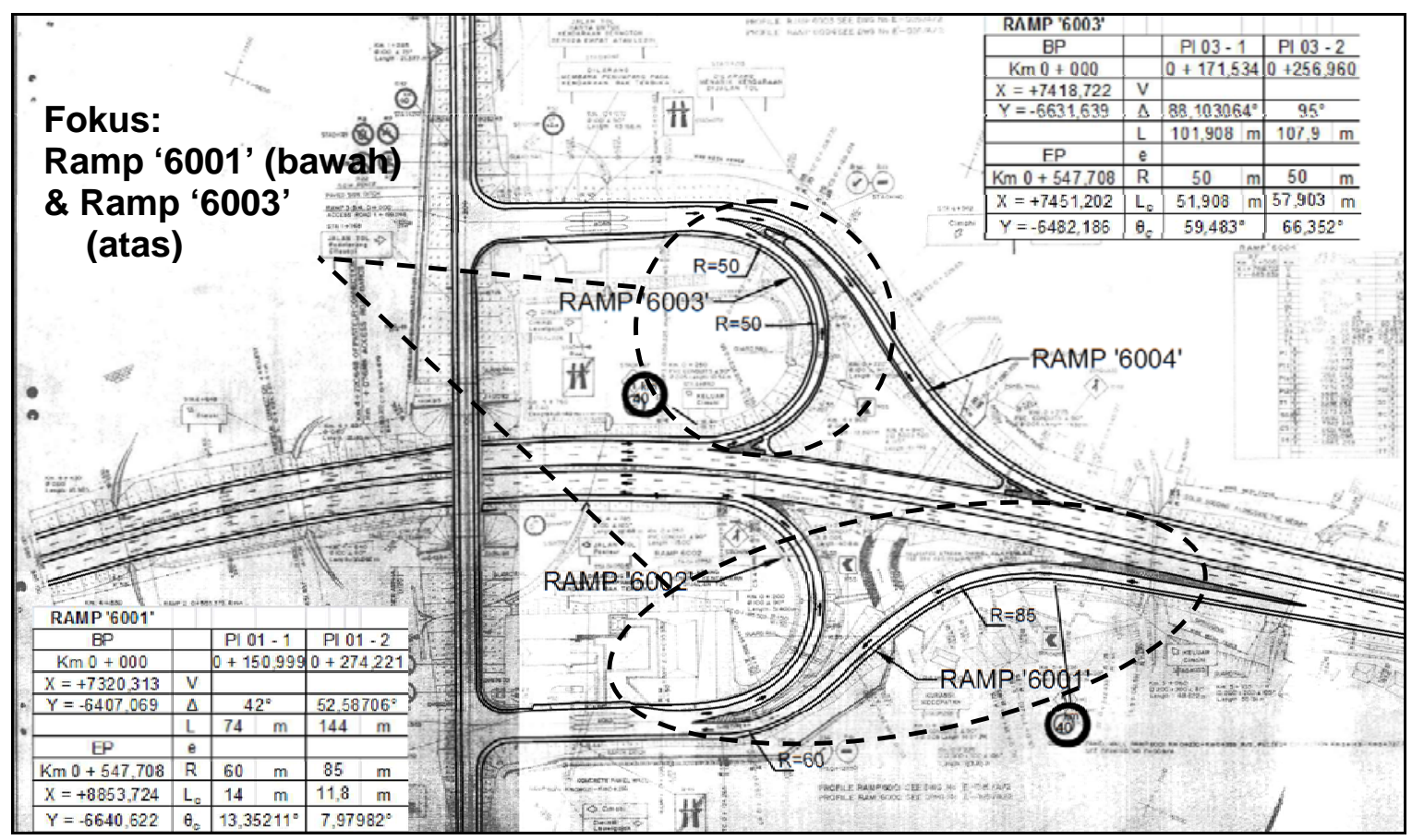

Gambar 3 Denah Simpang Susun Baros

\section{ANALISIS DATA DAN PEMBAHASAN}

\subsection{Perhitungan Volume Lalu Lintas Ramp}

Kemiringan vertikal terbesar ramp ' 6001 ' $\left(\mathrm{g}_{\text {maks }}\right)$ adalah $1,06 \%$ atau $10,6 \mathrm{~m} / \mathrm{km}$.

Dari Tabel 2, tipe alinemen untuk ramp '6001' adalah bukit. LHRT ramp '6001'diperoleh dari hasil perhitungan sebesar $13.896 \mathrm{smp} / \mathrm{hari}$ dan VJR ramp '6001' sebesar $1.529 \mathrm{smp} / \mathrm{jam}$ seperti ditunjukkan pada Tabel 8 .

Tabel 8 Perhitungan Volume Lalu Lintas Ramp ‘6001’

\begin{tabular}{lcrrr}
\hline Golongan Kend. & Kelompok & Volume (kend) & EMP & Volume (smp) \\
\hline Golongan I & KR & 3.668 .998 & 1 & 3.668 .998 \\
\hline
\end{tabular}




\begin{tabular}{lcrrr}
\hline Golongan Kend. & Kelompok & Volume (kend) & EMP & \multicolumn{1}{c}{ Volume (smp) } \\
\hline Golongan II & MHV & 506.784 & 1,8 & 912.211 \\
\hline Golongan III & LT & 119.772 & 3,5 & 419.202 \\
\hline Golongan IV & LT & 15.430 & 3,5 & 54.005 \\
\hline Golongan V & LT & 5.066 & 3,5 & 17.731 \\
\hline Jumlah & & 4.316 .050 & & 5.072 .147 \\
\hline LHRT & 11.825 & & 13.896 \\
\hline VJR & & 1.301 & 1.529 \\
\hline
\end{tabular}

Kemiringan vertikal terbesar ramp ' 6003 ' $\left(\mathrm{g}_{\text {maks }}\right)$ adalah sebesar $5,38 \%$ atau 53,8 $\mathrm{m} / \mathrm{km}$. Dari Tabel 2, tipe alinemen untuk ramp '6003' adalah gunung. LHRT ramp '6003'diperoleh dari hasil perhitungan sebesar 7.719 smp/hari dan VJR sebesar 849 smp/jam seperti ditunjukkan pada Tabel 9.

Tabel 9 Perhitungan Volume Lalu Lintas Ramp ‘6003’

\begin{tabular}{lcrrr}
\hline Golongan Kend. & Kelompok & Volume (kend) & EMP & Volume (smp) \\
\hline Golongan I & KR & 2.528 .177 & 1 & 2.528 .177 \\
\hline Golongan II & MHV & 87.360 & 2,5 & 218.400 \\
\hline Golongan III & LT & 15.258 & 4,6 & 70.187 \\
\hline Golongan IV & LT & 84 & 4,6 & 386 \\
\hline Golongan V & LT & 37 & 4,6 & 170 \\
\hline Jumlah & & 2.630 .916 & & 2.817 .320 \\
\hline LHRT & 7.208 & & 7.719 \\
\hline VJR & 793 & 849 \\
\hline
\end{tabular}

\subsection{Perhitungan Kapasitas Ramp}

Dengan tipe alinemen termasuk bukit, kapasitas dasar $\left(\mathrm{C}_{0}\right)$ ramp '6001' adalah $1850 \mathrm{smp} / \mathrm{jam}$ (Tabel 1). Faktor penyesuaian akibat lebar jalur lalu lintas $\mathrm{FC}_{\mathrm{W}}$ sebesar 1,03 (Tabel 3). Faktor penyesuaian kapasitas akibat arah $\left(\mathrm{FC}_{\mathrm{SP}}\right)$ tidak dapat diterapkan 
pada jalan dengan satu jalur sehingga dapat dianggap bernilai 1,0. Kelas hambatan samping pada ramp '6001' ditentukan dengan mempertimbangkan bahwa ramp masih berada di dalam ruas Tol Pasteur sehingga kelas hambatan samping dapat dikategorikan sangat rendah $(\mathrm{VL})$. Faktor penyesuaian akibat hambatan samping $\left(\mathrm{FC}_{\mathrm{SP}}\right)=0,99$ (Tabel 5). Dari Persamaan 1, kapasitas (C) ramp '6001'adalah sebesar 1886 smp/jam.

Ramp '6003' memiliki tipe alinemen gunung sehingga kapasitas dasarnya $\left(\mathrm{C}_{0}\right)$ adalah $1800 \mathrm{smp} / \mathrm{jam}$ (Tabel 1). Faktor penyesuaian akibat lebar jalur lalu lintas $\mathrm{FC}_{\mathrm{W}}$ sebesar 1,03 (Tabel 3). Faktor penyesuaian kapasitas akibat arah $\left(\mathrm{FC}_{\mathrm{SP}}\right)$ tidak dapat diterapkan pada jalan dengan 1 jalur sehingga dapat dianggap bernilai 1,0. Kelas hambatan samping pada ramp '6003' ditentukan dengan sangat rendah (VL). Faktor penyesuaian akibat hambatan samping $\left(\mathrm{FC}_{\mathrm{SP}}\right)=0,99$ (Tabel 5). Kapasitas ramp '6003' dari hasil perhitungan adalah $1.835 \mathrm{smp} / \mathrm{jam}$.

\subsection{Analisis Derajat Kejenuhan Ramp}

Dari perhitungan dengan VJR sebesar 1.529 smp/jam dan C sebesar 1.886 smp/jam, ramp '6001' memiliki derajat kejenuhan sebesar 0,81. Derajat kejenuhan kurang dari 1. Ini berarti kapasitas jalan masih cukup menampung kendaraan yang melalui ramp '6001'. Oleh karena itu, ramp '6001' belum memerlukan peningkatan kapasitas.

Sementara pada ramp '6003' dengan VJR sebesar 800 smp/jam dan C sebesar $1.835 \mathrm{smp} / \mathrm{jam}$, derajat kejenuhan diperoleh sebesar 0,46. Derajat kejenuhan pada ramp '6003' juga bernilai kurang dari 1. Ini berarti kapasitas ramp '6003'masih cukup menampung kendaraan yang lewat. Oleh karena itu, ramp '6003' belum memerlukan peningkatan kapasitas.

\subsection{Analisis Tingkat Pelayanan Ramp}

Berdasarkan Tabel 7, untuk jalan dengan tingkat kejenuhan lalu lintas/derajat kejenuhan sebesar 0,81 (di antara 0,77-0,93), Ramp '6001' memiliki tingkat pelayanan "D". Berdasarkan Tabel 7, untuk jalan dengan tingkat kejenuhan lalu lintas/derajat kejenuhan sebesar 0,46 (di antara 0,35-0,54), Ramp '6003' memiliki tingkat pelayanan "B”. Arus lalu lintas pada Ramp '6003' lebih rendah dibandingkan arus lalu lintas pada Ramp '6001'. Hal ini dikarenakan arus lalu lintas pada Ramp '6003' hanya berasal dari Kota Bandung, khususnya dari Gerbang Tol Pasteur. Sementara arus lalu lintas pada Ramp '6001' dapat berasal dari luar Kota Bandung. 


\subsection{Analisis Tingkat Pertumbuhan Lalu Lintas}

Volume kendaraan selama tiga bulan pada bulan Januari 2014 hingga Maret 2014 yang melalui Gerbang Tol Baros 1 dan 2 adalah sebanyak 3.317.565 kendaraan. Pada tahun berikutnya, Volume kendaraan pada bulan Januari 2015 hingga Maret 2015 tercatat sebanyak 3.370.429 kendaraan. Terdapat peningkatan volume kendaraan sebesar 53.136 kendaraan atau sebesar $1,59 \%$ per tahun.

\subsection{Perkiraan umur rencana ramp '6001'}

Umur rencana ramp diperkirakan dengan mengasumsikan volume lalu lintas telah mencapai kapasitas jalan.

$$
\begin{aligned}
& \mathrm{V}_{\mathrm{T}} \quad=\mathrm{C}=1.886 \mathrm{smp} / \mathrm{jam} \\
& \mathrm{V}_{0} \quad=\mathrm{VJR}=1.529 \mathrm{smp} / \mathrm{jam} \\
& V_{\mathrm{T}}=V_{0} x(1+1)^{n} \\
& 1.886=1.529 \times(1+0,0159)^{n} \\
& \mathrm{n}^{\prime}=\log 1,01 \% \mathrm{f}\left(\frac{1.886}{1.526}\right) \\
& \mathrm{n}^{\prime}=13,30 \text { tahun } \approx 13 \text { tahun } \\
& 2014+13=2027
\end{aligned}
$$

Jadi, diperkirakan pada tahun 2027 volume lalu lintas pada ramp '6001' akan menyamai kapasitasnya.

\subsection{Perkiraan umur rencana ramp '6003'}

$\mathrm{V}_{\mathrm{T}}=\mathrm{C}=1.835 \mathrm{smp} / \mathrm{jam}$

$\mathrm{V}_{0}=\mathrm{VJR}=800 \mathrm{smp} / \mathrm{jam}$

$\mathrm{V}_{\mathrm{T}}=\mathrm{V}_{0} \times(1+1)^{n}$

$$
1.839=800 \times(1+0,0139)^{n \prime}
$$

$n^{\prime}=\log$ l,019 $\left(\frac{1,659}{849}\right)$

$\mathrm{n}^{\prime}=48,85$ tahun $\approx 49$ tahun

$2014+49=2063$

Jadi, diperkirakan pada tahun 2063 volume lalu lintas pada ramp '6003' akan menyamai kapasitasnya. 


\section{KESIMPULAN DAN SARAN}

Ramp '6001' memiliki tingkat pelayanan "D" pada tahun 2014 dengan derajat kejenuhan sebesar 0,81. Dengan memperhitungkan tingkat pertumbuhan lalu lintas sebesar 1,59\% per tahun, volume lalu lintas ramp '6001' diperkirakan mencapai kapasitas jalan pada tahun 2027 .

Ramp '6003' memiliki tingkat pelayanan "B" pada tahun 2014 dengan derajat kejenuhan sebesar 0,46. Dengan memperhitungkan tingkat pertumbuhan lalu lintas sebesar 1,59\% per tahun, volume lalu lintas ramp ‘6003' diperkirakan mencapai kapasitas jalan pada tahun 2063 .

\section{DAFTAR PUSTAKA}

1. American Association of State Highway and Transportation Officials (AASHTO), (2001), A Policy on Geometric Design of Highways and Streets, American Association of State Highway and Transportation Officials.

2. Direktorat Jenderal Bina Marga, (1997), Manual Kapasitas Jalan Indonesia (MKJI), Direktorat Jenderal Bina Marga, Jakarta.

3. Keputusan Menteri Pekerjaan Umum No. 730/KPTS/M/2007 Tahun 2007 tentang Penetapan Golongan Jenis Kendaraan Pada Ruas Jalan Tol yang Sudah Beroperasi dan Besarnya Tarif Tol Pada Beberapa Ruas Jalan Tol.

4. Peraturan Menteri Perhubungan Nomor KM 14 Tahun 2006 tentang Manajemen dan Rekayasa Lalu Lintas di Jalan .

5. Sukirman, S., (1999), Dasar-dasar Perencanaan Geometrik Jalan, Nova, Bandung.

6. Susilo, B.H., (1999), Diktat Kuliah Perencanaan Perkerasan Lentur Jalan, Jurusan Teknik Sipil, Fakultas Teknik Universitas Kristen Maranatha, Bandung.

7. Susilo, B.H., (2015), Rekayasa Lalu Lintas, Edisi Kedua, Penerbit Trisakti, Jakarta.

8. Tamin, O.Z., .(2000), Perencanaan dan Pemodelan Transportasi, ITB, Bandung.

Evaluasi Tingkat Pelayanan Ramp Simpang Susun Baros (Budi Hartanto Susilo, Ivan Imanuel) 